ABDI: Jurnal Pengabdian dan Pemberdayaan Masyarakat ISSN: 2656-369X (Print), 2684-8570 (Online)

Volume 3 No. 2, Desember 2021

http://abdi.ppj.unp.ac.id/index.php/abdi

Email: abdi@ppi.unp.ac.id

DOI: https://doi.org/10.24036/abdi.v3i2.82

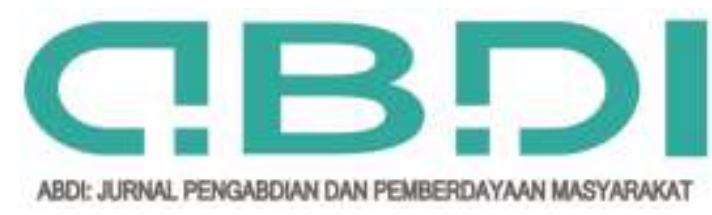

\title{
Pemberian Latihan Senam Aerobik Low Impact Terhadap Warga Tahanan di Rutan Kelas II B Karimun Kab. Tanjung Balai Karimun
}

\author{
Hilda Oktri Yeni ${ }^{1}$, Fadli Surahman², Rahmat Sanusi ${ }^{3}$ \\ ${ }^{1,2,3}$ Universitas Karimun \\ E-mail: hildaoktriyeni@gmail.com, fadlisurahman89@yahoo.com, rahmatsanusi25@gmail.com
}

\begin{abstract}
Abstrak
Kegiatan pengabdian masyarakat senam Aerobik yang dilaksanakan seluruh warga rutan kelas II B karimun, adapun tujuan dari program pengabdian ini dapat membawa manfaat warga rutan dalam kebugaran jasmani dan rohani dan perduli terhadap pertumbuhan dan perkembangan organ-organ tubuh baik dalam pembentukan tubuh yang sehat dan ideal kegiatan ini dilaksanakan mulai tanggal 22 April 2017 setiap hari sabtu pagi. Pelaksnakan senam Aerobik ini dilaksanakan 382 peserta atau lebih seluruh warga tahanan dan pegawai lapas, pelaksanaan ini dibagi dua kelompok, minggu pertama kelompok A dan minggu kedua kelompok B sampai seterusnya, karna dipengaruhi fasilitas lapangan yang tidak memungkinkan. Kegiatan pelatihan senam Aerobik dilakukan selama 3 bulan berjalan dengan lancar dan efektif. Meteri kegiatan yang dilakukan senam aerobik low impact mulai dari gerakan pemanasan, peregangan dan gerakan inti serta pendinginan. Tugas yang diberikan hanya menghapal dan melakukan gerakan senam aerobic low impact, senam aerobic dengan benturan ringan dalam variasi gerakannya, hanya saja dilakukan dengan irama rendah dengan gerakan yang mudah diingat tujuan senam aerobic low impact bukan senam untuk menurunan berat badan yang dilakukan. Tujuannya untuk memberikan kesehatan dan kebugaran jasmani bagi warga rutan. Hasil dari evaluasi dilakukan hanya beberapa yang belum hafal gerakan inti dan pendinginan, hasil dari gerakan mereka tidak sempurna tapi menunjukan kebahagiaan untuk mereka. Selain itu irama gerakan yang rendah musiknya bisa dinikmati secara nyaman sehingga menumbuhkan semangat dengan riang gembira selain itu aerobic low impact ini dapat meningkatkan paru-paru, jantung, peredaran darah bagi warga tahanan rutan begitu juga pegawai tahanan rutan kelas IIB tanjung balai karimun.
\end{abstract}

Kata Kunci. Latihan Senam Aerobik, Low Impact, Warga Tahanan di Rutan

Abstract

Aerobic gymnastics community service activities carried out by all members of Class IIb Karimun remand center, as for the purpose of this service program is to benefit remand residents in physical and spiritual fitness and care for the growth and development of body organs both in the formation of a healthy and ideal body for this activity held starting April 22, 2017 every Saturday morning. The implementation of Aerobic exercise was carried out by 382 participants or more of all prisoners and prison staff, this implementation was divided into two groups, the first week of group A and the second week of group B onwards, because it was influenced by impossible field facilities. Aerobics training activities carried out for 3 months run smoothly and effectively. The activities carried out by low impact aerobic exercise start from warming up, stretching and core movements as well as cooling. The tasks given are only memorizing and doing low impact aerobic exercise, aerobic exercise with light impact in a variety of movements, it's just done with a low rhythm with movements which is easy to remember. the goal of low impact aerobic exercise is not exercises to lose weight that is done. The goal is to provide health and physical fitness for prison residents. The results of the evaluation were carried out only a few who had not memorized the core and cooling movements, the results of their movements were not perfect but showed happiness for them. Apart from that, the rhythm of the movement with low music can be enjoyed comfortably so that it fosters a cheerful spirit. In addition, this low impact aerobic can improve the lungs, heart, blood circulation for prisoners of remand center as well as class IIB prison staff of Tanjung Balai Karimun.

Keywords: Aerobic Exercise, Low Impact, Prisoners at the Detention Center

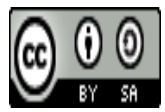

Received: 12 November 2020 Revised: 2 Agustus 2021 Available Online: 20 Agustus 2021

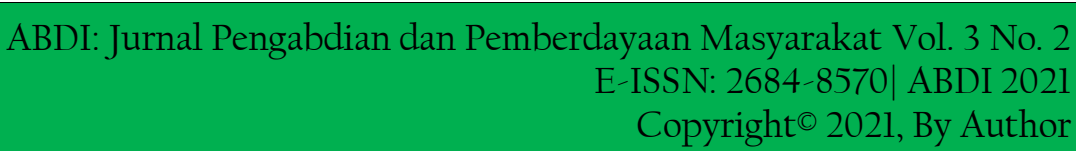


Hilda Oktri Yeni, Fadil Surahman, Rahmat Sanusi Pemberian Latihan Senam Aerobik Low Impact Terhadap Warga tahanan di Rutan Kelass II B Kab. Tanjung Balai Karimun

\section{Pendahuluan}

Senam pada dasarnya sebuah aktifitas gerakan yang dilakukan pada tubuh manusia, memiliki banyak manfaat meningkatkan kesehatan baik dalam stamina tubuh maupun jantung. Senam sebagai alat penurunan berat badan, senam salah satu bagian dalam aktivitas olahraga dalam bentuk aktivitas fisik, dilakukan oleh masyarakat, dituntut selalu bergerak demi hidup sehat baik jasmani dan rohani.

Kegiatan fisik yang dilakukan dan diterapkan kedalam masyarakat yaitu olahraga senam, Senam adalah latihan tubuh yang diciptakan dengan sengaja, disusun secara sistematika, dan dilakukan secara sadar dengan tujuan untuk membentuk dan mengembangkan pribadi secara harmonis (Widianti \& Proverawati, 2010). Senam adalah Senam adalah latihan yang dilakaukan secara sengaja, dengan terencana, dan sistematis untuk meberikan gerakan yang di inginkan (Suherman, 2010). Senam ini bertujuan untuk meningkatkan efisiensi pemasukan oksigen di dalam jaringan tubuh. Kadar oksigen yang masuk tersebut ditentukan oleh besarnya kapasitas paru-paru saat menghirup udara (Mattioli, Pinti, Farinetti, \& Nasi, 2020).

Sedangkan Aerobik adalah sebuah aktifitas yang menyenangkan dan mudah dilakukan (Brick, 2002). Senam aerobik merupakan latihan yang menggabungkan berbagai gerak, berirama, teratur dan terarah serta pembawaannya yang menggembirakan arena didukung jenis musik yang riang akan tetapi sebelum melakukan gerakan senam masyarakat dianjurkan menggunakan hand sanitaizer, yang berguna untuk menjaga kebeersihan tangan, pasalnya tangan adalah bagian bagian tubuh yang sangat rentan dan dapat dengan mudah menjadi/tempat bersarangnya virus dan bakteri (Hellerstein, 2020). Senam aerobik merupakan olahraga untuk peningkatan kesegaran jasmani, meningkatkan daya tahan jantung dan paru-paru, meningkatkan kekuatan otot, meningkatkan kelentukan, dapat mengurangi kebosanan, stress, dan lain sebagainya hal positif yang dapat dirasakan manfaatnya bagi pesenam yang aktif mengikuti senam dan dapat dilakukan secara masal. Berdasarkan menurut para ahli di atas senam aerobic merupakan olahraga yang dapat meningkatkan kebugaran jasmani serta dapat meningkatkan kondisi fisik umum seperti daya tahan tubuh, kekuatan, kelentukan, koordinasi, membentuk prestasi, membentuk tubuh yang ideal, dan memelihara kesehatan tubuh serta dapat menguruangi stress atau kebosanan seseorang (Nugraheningsih \& Saputro, 2020).

Manfaat senam Aerobik dapat menguatkan daya tahan jantung dan paru-paru, serta mengencangkan dan pembentukan otot bagian tubuh. Senam aerobic bisa dilakukan dengan intesitas sedang dapat dilakukan semua umur dengan gerakan- gerakan yang mudah dipahami dan dilakukan secara tersusun,teratur dan berulang, hal ini juga disampaikan oleh (Candrawati, S., Sulistyoningrum, Agung Prakoso, \& Pranasari, 2016). Latihan aerobik yang dilakukan secara teratur dengan takaran yang cukup akan memerbaiki kinerja jantung dan paru-paru. Selain itu senam aerobik banyak diminati oleh masyarakat sebagai alternatif kegiatan olahraga dengan tujuan untuk menurunkan berat badan, membentuk tubuh, menjaga kebugaran jasmani, meningkatkan kualitas hidup, dan lain sebagainya (Alex \& Subiyono, 2012).

Senam Aerobik termasuk salah satu program masyarakat dan pemerintah di tanjung balaikarimun, salah satu program kegiatan pemerintah yaitu senam bersama dirutan Kelas IIb Tanjung Balaikarimun,program tersebut betujuan untuk memberikan kesehatan jasmani dan rohani warga binaan, informasi dari kepala rutan menyatakan bahwa ada warga binaan mencapai 382 orang melebih kapasitas daya tampung 200 orang,sebagai warga binaan bisa melakukan kegiatan rutin setiap hari sabtu, kepala rutan juga mengatakan bahwa tujuan senam aerobic dilakukan dirutan bertujuan memberikan peningkatkan taraf tubuh, warga binaan yang sudah lama berada disel tahanan. Senam aerbic bukan hanya untuk tahanan saja tapi untuk seluruh pegawai rutan.

Menurut pendapat diatas bahwa Senam Aerobik merupakan senam yang dapat ,membentuk dan mengembangkan pribadi yang baik secara sadar disusun dengan gerakan sistematis dan mudah dilakukan serta menyenangkan, senam aerobik untuk pemula biasa disebut senam aerobic yaitu latihan senam yang gerakannya menggunakan seluruh otot, terutama otot-otot besar, sehingga memacu kerja jantung paru, dan gerakan-gerakan badan secara berkesinambungan pada bagian-bagian badan bentuk gerakan-gerakan dengan satu atau dua kaki tetap menempel pada lantai serta diiringi music. Menurut (Agdila, 2012) yaitu: 
Hilda Oktri Yeni, Fadil Surahman, Rahmat Sanusi

\begin{abstract}
pengertian senam Aerobik" (a) gerakan-gerakan selalu dibuat atau diciptakan dengan sengaja, gerakan gerakannya selalu harus berguna untuk mencapai tujuan tertentu (misalnya: pembentukan sikap tubuh, memperbaiki gerak, meningkatkan taraf tubuh, memperbaiki gerak, meningkatkan tarf kesegaran, sebagai sarana rahabilitasi), (b) gerakan-gerakannya harus tersusun dan sistematik, (c) dilakukan secara terartur dan berulang".
\end{abstract}

Menurut pendapat di atas bahwa senam aerobic merupakan gerakan yang disegaja untuk mencapai tujuan dalam meningkatkan taraf tubuh, perbaiki gerak, meningkatkan taraf kesegaran dengan secara sistematik dan tersusun yang dilakukan secara berulang ulang pada bagian tubuh. Gerakan senam Aerobik juga bermanfaat bagi masyarakat pada umumnya dari aktifitas kerja seharihari sehingga otot terasa kaku kesegaran menurun dan merasa cepat lelah.

Senam Aerobik ini sangat mudah dan bagus untuk di ikuti oleh semua kalangan masyarakat dan Kegiatan ini dinilai positif untuk memberikan yang terbaik untuk warga tahanan rutan dan pegawai rutan, membuat mereka sehat jasmani dan rohani dapat mengerakan otot-otot yang kaku karna berada dalam ruangan tahanan yang tertutup, ditambah dengan alunan irama music yang menarik dan gerakan mudah dan menyenangkan. Senam yang akan dilakukan senam Aerobic low impact. Senam aerobic low impact adalah senam aerobic benturan ringan dalam variasi gerakannya, hanya saja dilakukan dengan irama rendah (low) yaitu lebih lambat (Hasanah, 2006). Untuk senam aerobic dilakukan dengan beberapa gerakan yang harus diperhatikan (1) gerakan kaki: gerakan kaki merupakan gerakan dasar yang penting dan harus diperhatikan sebelum dilakukan dengan gerakan tangan. (2) gerakan lengan: merupakan rangkaian gerakan koordinasi dengan kaki,tangan tujuan agar seluruh komponen tubuh dapat bergerak dengan aktif secara maksimal (Alim, 2011) (Kusumaningtyas, 2011).

Menurut pendapat diatas menunjukan gerakannya, hanya saja dilakukan dengan irama rendah (low) gerakan dasar yang akan dilakukan gerakan kaki dan tangan yang menunjukan seleuruh komponen gerakan pada tubuh dapat bergerak dengan aktif dan maksimal. Untuk intesitas latihan yang digunakan sesuai tujuan serta jenis senam aerobic yang akan dilakukan. Beberapa contoh intensitas latihan dan kebutuhan diantaranya:

1. Memperbaiki Kesegaran Jasmani

(a) Intensitas Latihan: 70-85 dari denyut nadi maksimal (DNM)

(b) Lama latihan : 20-30 menit

(c) Frekunsi latihan; 3 kali seminggu

2. Menurunkan berat badan dan lemak

(a) Intesitas latihan: 70-85\% dari denyut nadi maksimal (DNM)

(b) Lama latihan: 30 menit atau lebih

(c) Frekunsi latihan : 4 kali seminggu

3. Mengurangi resiko penyakit jantung coroner

(a) Intensitas latihan: $70-85 \%$ dari denyut nadi maksimal

(b) Lama latihan: antara 30-45 menit

(c) Frekuensi latihan : 3 kali semiggu

4. Mengurangi gangguan mental

(a) Intensitas latihan: 70-85\% dari denyut nadi maksimal (DNM)

(b) Lama latihan: antara 45-60 menit

(c) Frekuensi latihan: 3 kali seminggu

5. Mengurangi tekanan darah tinggi

(a) Intensitas Latihan: lebih rendah, artinya latihan tidak perlu sampai masuk dalam target-target tinggi tetapi cukup berlatih dengan senang, gembira, enak sesuai dengan kemampuan tubuh.

(b) Lama latihan: lebih kurang 30 seminggu

(c) Frekuensi latihan: 5 kali seminggu (Jonni, 2003). 
Hilda Oktri Yeni, Fadil Surahman, Rahmat Sanusi Pemberian Latihan Senam Aerobik Low Impact Terhadap Warga tahanan di Rutan Kelass II B Kab. Tanjung Balai Karimun

\section{Metode Pelaksanaan}

\subsection{Waktu dan Tempat Penelitian}

Kegiatan pelatihan ini direncanakan selama 3 bulan dilaksanakan pada tanggal mulai 22 April 2017, setiap hari sabtu pagi jam 07.30 lokasi pelaksanaan dilapangan Tahanan Negara Kelas IIB Tanjung Balai Karimun terletak di kelurahan Teluk Air Kecamatan Karimun Kabupaten Karimun. Kegiatan ini di ikuti sekitar setengah dari warga tahanan rutan dan pegawai rutan laki-laki dan perempuan, warga rutan tidak semuanya yang ikut serta karna keterbatasan lapangan. Kegiatan yang dilakukan dibantu oleh 3 orang mahasiswa penjasksrek dibidang senam. Sebelum dimulai pelatihan terlebih dahulu memperkenalkan senam aerobic low impact dengan senam lainnya serta memilih irama music yang akan dibunyikan sesuai dengan keinginan dari warga rutan. Setelah itu dilanjutkan warga rutan untuk memberikan pertanyaan dan saran.

\subsection{Tata cara senam Aerobik Low Impact}

Tata cara senam aerobic low impact yang akan dilakukan yaitu mencari pola gerakan yang mudah dan cepat diingat, pola gerakan yang berbeda tapi tidak mengikat bagi warga rutan karna tujuan senam aerobic untuk meningkatkan kesehatan tubuh dan memperbaiki gerak.

\subsection{Pelaksanaan pelatihan senam aerobic low impact}

Untuk pelaksanaan pelatihan senam aerobic low impack mengikuti tahap yaitu: persiapan, pelaksanaan, evaluasi sebagai berikut:

\subsubsection{Persiapan}

Tahap persiapan yang dilakukan oleh pengabdi yaitu melakukan observasi untuk menentukan senam aerobic low impact yang akan dilakukan berdasarkan permasalahan yang dibutuhkan oleh mitra disebut kepala rutan tanjung balai karimun, strategi yang akan dilakukan oleh pengabdi adalah mencari irama music yang lagi tren serta mencari pola gerakan yang mudah disukai, dan hasil dari persiapan disosialisasi juga bersama kepala rutan dan pegawai rutan.

Persiapan yang akan dilakukan oleh Insruktur senam sebelum dimulai kegiatan:

a. Instruktur harus memberikan gerakan pemanasan terlebih dahulu selama 10-15 menit

b. Instruktur menyiapkan musik untuk setiap gerakan

c. Menyiapkan gerakan untuk senam aerobic low impact

Persiapan yang akan dilakukan oleh peserta senam (pegawai tahanan dan warga tahanan rutan) sebelum dimulai kegiatan:

a. Harus menggunakan pakaian olahraga

b. Peserta benar-benar dalam keadaan sehat dan siap melaksanakan tes denyut nadi

c. Melakukan gerakan pemanasan terlebih dahulu 10-15 menit (senam SKJ)

\subsubsection{Pelaksanaan}

Ditahap pelaksanaan kegiatan ini juga dilakukan oleh pegabdi melakukan sebagai berikut: Pengabdi mempersiapkan alat musix yang sudah disediakan oleh pihak rutan. Pengabdi memperkenalkan civitas akademik berserta mahasiswa, sebelum melakukan senam aerobic low impact. Memberikan arahan serta lama pelaksanaan yang akan dilakukan, menggunakan motode ceramah untuk memberikan wawasan. Pelaksanaan kegiatan pengabdian ini juga melibatkan kepala rutan dan pegawai rutan.

\subsubsection{Evaluasi}

Untuk tahap evaluasi yang dilakukan oleh tim pengabidan masyarakat untuk mengukur kemampuan dalam melakukan gerakan senam aerobic low impact tanpa ada instruktur senam dari dosen maupun mahasiswa. Pelaksanaan senam aerobik dilakukan secara bersama beserta pegawai rutan. Warga rutan juga diperbolehkan untuk salah satu warganya tampil didepan menjadi instruktur. 
Hilda Oktri Yeni, Fadil Surahman, Rahmat Sanusi Pemberian Latihan Senam Aerobik Low Impact Terhadap Warga tahanan di Rutan Kelass II B Kab. Tanjung Balai Karimun

Seluruh kegiatan pengabdian ini menggunakan pendekatan pasrtisipasi peserta warga rutan. Warga binaan rutan tidak cukup hanya mendengarkan tapi juga melakukan gerakan-gerakan senam aerobic low impact. Program pengabdian ini juga bertujuan memberikan kesehatan jasmani bagi warga rutan.

\section{Hasil dan Pembahasan}

Hasil yang diperoleh dalam pengabdian ini bersama warga rutan berdasarkan observasi yang dilakukan, serta pelaksanaan pengabdian yang yang dilaksanakan selama 3 bulan lamanya dengan mitra pimpinan dan pegawai Tahanan Negara Kelas IIB Tanjung Balai Karimun, dosen, mahasiswa serta warga tahanan berjalan dengan lancar dan efektif. Kegiatan ini diikuti sebanyak peserta. Pelaksanaan kegiatan senam aerobic low impact ini tidak semuanya yang ikut serta hanya sebagian saja karna keterbatasan lapangan yang tidak memadai melalui infomasi dari pimpinan.

Hasil dari kegiatan yang dilakukan dari mulai persiapan yaitu sosialisasi dan berbagai arahan bersama kepala rutan, pegawai didepan seluruh warga tahanan rutan tanjung balai karimun.

\section{Persiapan:}

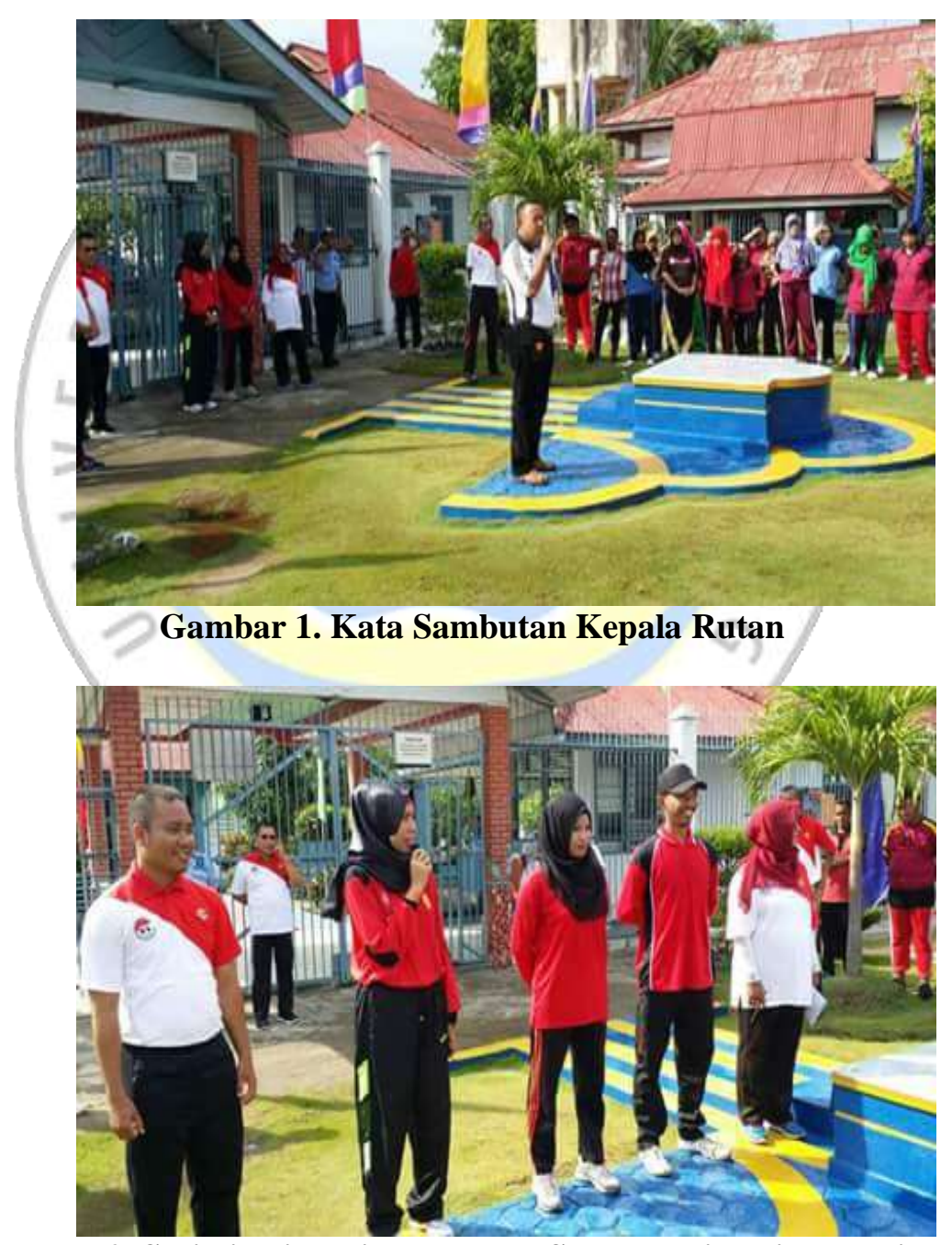

Gambar 2. Sosialisasi Dari Instruktur Senam Universitas Karimun

Berdasarkan gambar diatas, mempersiapan menjelang pelaksanaan, yaitu memberikan beberapa pengarahan dan arahan dalam proses pelaksanaan yang akan dijalani selama 3 bulan, kata sambutan berdasarkan dari pimpinan tahanan dan arahan materi pelaksanaan dari perwakilan dosen. 
Hilda Oktri Yeni, Fadil Surahman, Rahmat Sanusi

Kegiatan senam aerobic low impact dilaksanakan dilapangan Rutan Kelas II B Karimun yaitu pada kegiatan awalnya yaitu acara pembukaan oleh kepala rutan sendiri Bapak Eri Erawan. Kata sambutan diberikan dari Dosen Universitas Karimun sekaligus sebagai Instruktur senam Aerobik.

\section{Pelaksanaan:}

Kegiatan pelaksanaan yang dilakukan selama 3 bulan dimulai dari bulan April 2017- Juni 2017. Senam Aerobik merupakan gerakan-gerakannya selalu dibuat atau diciptakan dengan sengaja, gerakan-gerakannya selalu harus berguna untuk mencapai tujuan tertentu (misalnya: membentuk sikap tubuh, memperbaiki gerak, meningkatkan taraf kesegaran, sebagai sarana rehabilitasi), b) gerakan-gerakannya harus tersusun dan sistematik, c) dilakukan secara teratur dan berulang. Senam merupakan latihan tubuh yang diciptakan dengan sengaja, disusun secara sistematika,dan dilakukan secara sadar dengan tujuan untuk membentuk dan mengembangkan pribadi secara harmonis (Widianti \& Proverawati, 2010).

Maka menurut pendapat diatas merupakan senam aerobic low impact memiliki suatu gerakan yang dibuat dengan sengaja bertujuan untuk memperbaiki kondisi fisik pada tubuh manusia secara teratur dan berurang dalam meningkatkan kekuatan sendi dan bentuk tubuh manusia, senam aerobic low impact ini juga sangat bermanfaat untuk kebugaran jasmani khususnya pada peserta dan pegawai rutan baik ibu dan bapak.

Senam Aerobik yang dilaksanakan diRutan Kelas II B Karimun adalah senam Aerobik low impact adalah Gerakan senam aerobik low impact sangat sederhana tidak ada rangkaian yang rumit dan salah satu kaki selalu berada di lantai. Selain itu irama musiknya bisa dinikmati secara nyaman sehingga menumbuhkan semangat dengan riang gembira dan latihan senam aerobic low impact ini bertujuan untuk meningkatkan kemampuan paru-paru, jantung, peredaran darah peserta kalau mengikuti dengan yang sebenarnya dengan arahan instruktur.

Sebelum senam aerobic low impact yang dilakukan oleh peserta pada awalnya diberikan senam SKJ 2014 itu dilaksanakan setiap hari sabtu pagi menjelang senam aerobic low impact dimulai. Warga tahan rutan yang mengikuti senam aerobic low low impact semua umur, muda maupun tua dan lansia mereka tetap diberikan beberapa gerakan yang yang mudah dan tidak sulit, gerakan senam aerobic pada dasarnya dimulai dari pemanasan, peregangan, gerakan inti dan pendinginan. Untuk lama gerakan pemanasan yang digunakan adalah selama 10-15 menit, serta gerakan meregangkan otot. Untuk gerakan peregangan yang dilakukan gerakan pelan dan menahan. Dapat melindungi otot-otot dan syaraf reflek, untuk gerakan penenangan (coolin down) waktu yang saya gunakan adalah 10-15 menit sama dengan waktu pemanasan cukup untuk peserta pemula. Untuk gerakan inti ketukan 3x8 dengan 3 gerakan dengan pola langkah yang berbeda-beda dilakukan secara berulang-ulang waktu yang digunakan 10 menit.

Peserta tahan rutan juga lakukan mengukur denyut nadi maksimal 70-85\%, lama latihan antara 20-30 menit dan frekuensi latihan 1 kali seminggu saja karna kondisi yang tidak memungkikan buat warga rutan kalau dilakukan 3 kali seminggu. Disini difokuskan untuk memperbaiki kesegaran jasmani bukan untuk menurunkan berat badan dan lemak, dan apabila latihan senam aerobic low impact ada gejala atau permasalahan mulai kelelahan jantung,merasa pusing dan jantungnya lebih cepat, mual dan merasa lelah dan tidak bisa tidur berarti peserta tersebut kekurangan gizi maka peserta rutan dianjurkan untuk periksa kedokter.

Pelaksanaan kegiatan senam aerobic low impact berjalan efektif dengan partisipasi warga tahan rutan dan pegawai rutan dengan baik, sehingga koreksi yang diberikan instruktur senam menerima dengan baik. Mulai dari gerakan yang masih kaku mulai beransur-ansur membaik dari gerakan kaki tidak sesuai dengan irama music sekarang sudah mulai sesuai dengan pola gerakan sebenarnya, setalah gerakan mulai membaik mulai pada gerakan tangan serta dikombinasi dengan gerakan seluruh tubuh baru diirigi dengan music rikmit. Setelah itu secara bertahap dilanjutkan gerakan halus yang sudah dipahami oleh peserta dari gerakan sebelumnya, hanya untuk memperalus kembali, bagi peserta yang belum menguasai hanya melatih kembali dan mengikuti gerakan teman-temannya. 
Hilda Oktri Yeni, Fadil Surahman, Rahmat Sanusi Pemberian Latihan Senam Aerobik Low Impact Terhadap Warga tahanan di Rutan Kelass II B Kab. Tanjung Balai Karimun

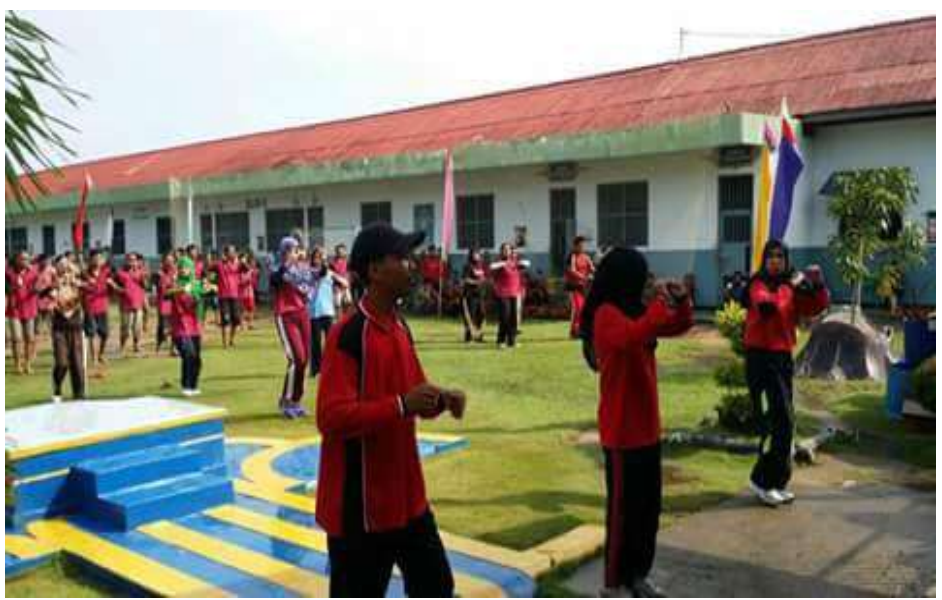

Gambar 3. Pelaksanaan Senam Aerobik dari Intruktur Mahasiswa dan Tahanan Ruta

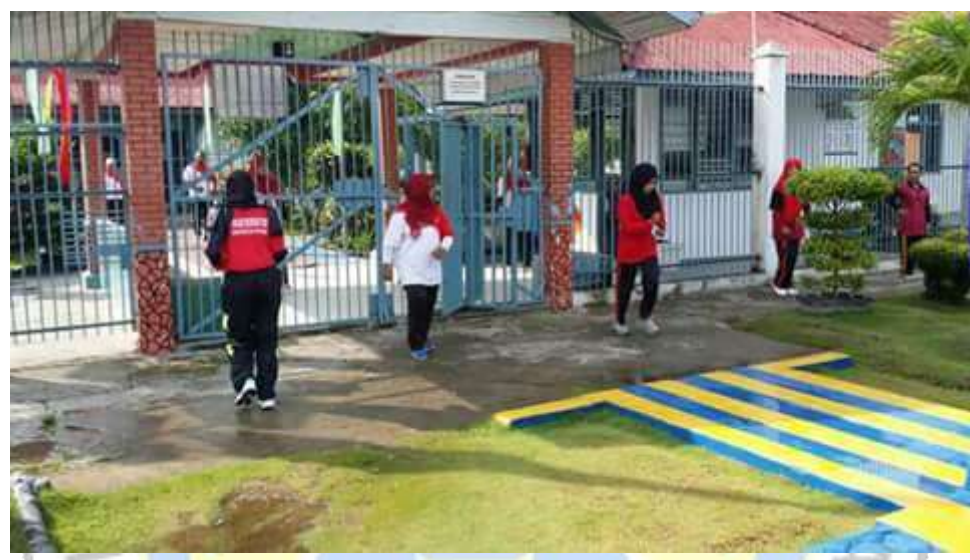

Gambar 4. Pelaksanaan Senam Aerobik dari Intruktur,

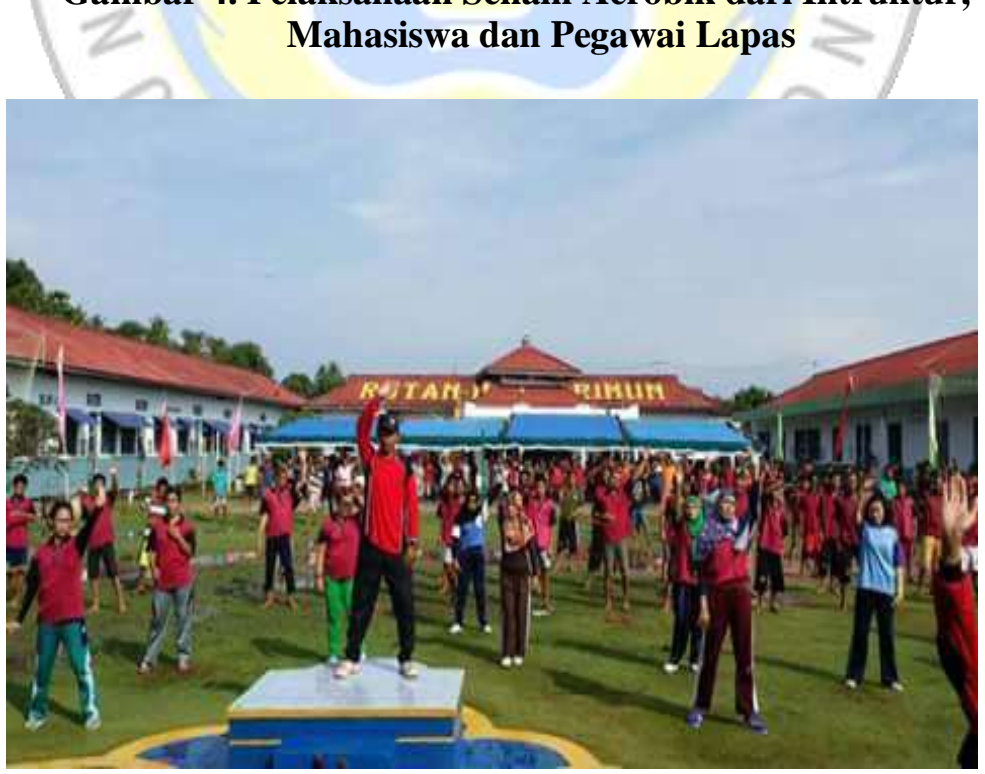

Gambar 5. Pelaksanaan Senam Aerobik 
Hilda Oktri Yeni, Fadil Surahman, Rahmat Sanusi Pemberian Latihan Senam Aerobik Low Impact Terhadap Warga tahanan di Rutan Kelass II B Kab. Tanjung Balai Karimun

\section{Evaluasi:}

Untuk tahap evaluasi yang dilakukan oleh tim pengabidan masyarakat untuk mengukur kemampuan dalam melakukan gerakan senam aerobic low impact tanpa ada instruktur senam dari dosen maupun mahasiswa.

Hasil dari evaluasi menunjukan perubahan meningkatan walaupun tidak tidak semuanya peserta yang hapal gerakan tapi ada beberapa peserta rutan yang jenis kelamin perempuan, hanya beberapa koreksi dengan gerakan inti hanya untuk memperalus kembali, tetap berlatih dengan mengikuti gerakan teman-temannya yang sudah bisa dan mampu menghapal gerakan yang dipelajari selama 3 bulan ini.

\section{Kesimpulan}

Kegiatan pelatihan senam aerobik dilakukan selama 3 bulan berjalan dengan lancar dan efektif. Meteri kegiatan yang dilakukan senam aerobik low impact mulai dari gerakan pemanasan,peregangan dan gerakan inti serta pendinginan.Tugas yang diberikan hanya menghapal dan melakukan gerakan senam aerobic low impact, senam aerobic dengan benturan ringan dalam variasi gerakannya, hanya saja dilakukan dengan irama rendah dengan gerakan yang mudah diigat.tujuan senam aerobic low impact bukan senam untuk menurunan berat badan yang dilakukan. Tujuannya untuk memberikan kesehatan dan kebugaran jasmani bagi warga rutan. Hasil dari evaluasi dilakukan hanya beberapa yang belum hafal gerakan inti dan pendinginan, hasil dari gerakan mereka tidak sempurna tapi menunjukan kebahagiaan untuk mereka. Selain itu irama gerakan yang rendah musiknya bisa dinikmati secara nyaman sehingga menumbuhkan semangat dengan riang gembira selain itu aerobic low impact ini dapat meningkatkan kemampuan paru-paru, jantung, peredaran darah bagi warga tahanan dan pegawai tahanan negara kelas IIB tanjung balai karimun.

\section{Daftar Pustaka}

Agdila, A. (2012). Perbedaan pengaruh latihan senam aerobic low impact dan senam body language terhadap penurunan berat badan pada kelompok ibu-ibu pemula dikarangasem 2012. Universitas Sebelas Maret.

Alex, M. S., \& Subiyono, H. S. (2012). Pengaruh Latihan Senam Aerobik Low Impact dan High Impact Terhadap Kesegaran Jasmani. Journal of Sport Science and Fitness, 1(1), 1-10.

Alim, A. (2011). Pengaruh Aktivitas Aerobik Terhadap Perubahan Penurunan Lemak Pada Sanggar Segar. Universitas Negeri Yogyakarta.

Brick, L. (2002). Bugar dengan senam Aerobik. Jakarta: Cerdas Jaya.

Candrawati, S., Sulistyoningrum, E., Agung Prakoso, D. B., \& Pranasari, N. (2016). Senam Aerobik Meningkatkan Daya Tahan Jantung Paru dan Fleksibilitas. Jurnal Kedokteran Brawijaya, 29(1), 6973.

Hasanah, N. (2006). Perbedaan pengaruh latihan senam aerobic low impack dan body language terhadap persentase lemak tubuh ibu-ibu anggota sanggar senam yunita demak. Semarang. Universitas Negeri Semarang.

Hellerstein, M. (2020). What are the roles of antibodies versus a durable, high quality T-cell response in protective immunity against SARS-CoV-2? Vaccine: $X, 6(1), 1-5$.

Jonni, J. (2003). Senam Aerobik. Padang: Fakultas Ilmu keolahragaan Universitas Negeri Padang.

Kusumaningtyas, D. N. (2011). Pengaruh Senam Aerobik Intensitas Ringan dan Sedang Terhadap Penurunan Persentase Lemak Badan. Fisioterapi Fakultas Ilmu Kesehatan Universitas Muhammdiyah Sukarta. Universitas Muhammadiyah SUrakarta.

Mattioli, A. V., Pinti, M., Farinetti, A., \& Nasi, M. (2020). Obesity risk during collective quarantine for the COVID-19 epidemic. Obesity Medicine, 20(1), 1-5.

Nugraheningsih, G., \& Saputro, Y. . (2020). Hasil Pengabdian Pada Masyarakat Pelatihan Senam Aerobik Untuk Meningkatkan Kebugaran Jasmani. Prosiding Konferensi Pendidikan Nasional "Strategi Dan Implementasi Pendidikan Karakter Pada Era Revolusi Industri 4.0." 
Hilda Oktri Yeni, Fadil Surahman, Rahmat Sanusi Pemberian Latihan Senam Aerobik Low Impact Terhadap Warga tahanan di Rutan Kelass II B Kab. Tanjung Balai Karimun

Suherman, A. (2010). Model Pembelajaran Pakem Dalam Pendidikan Jasmani Di Sekolah Dasar. Jurnal Penelitian Pendidikan, 11(1), 131-141.

Widianti, A. T., \& Proverawati, A. (2010). Senam Kesehatan. Yogayakarta: Nuha Medika.

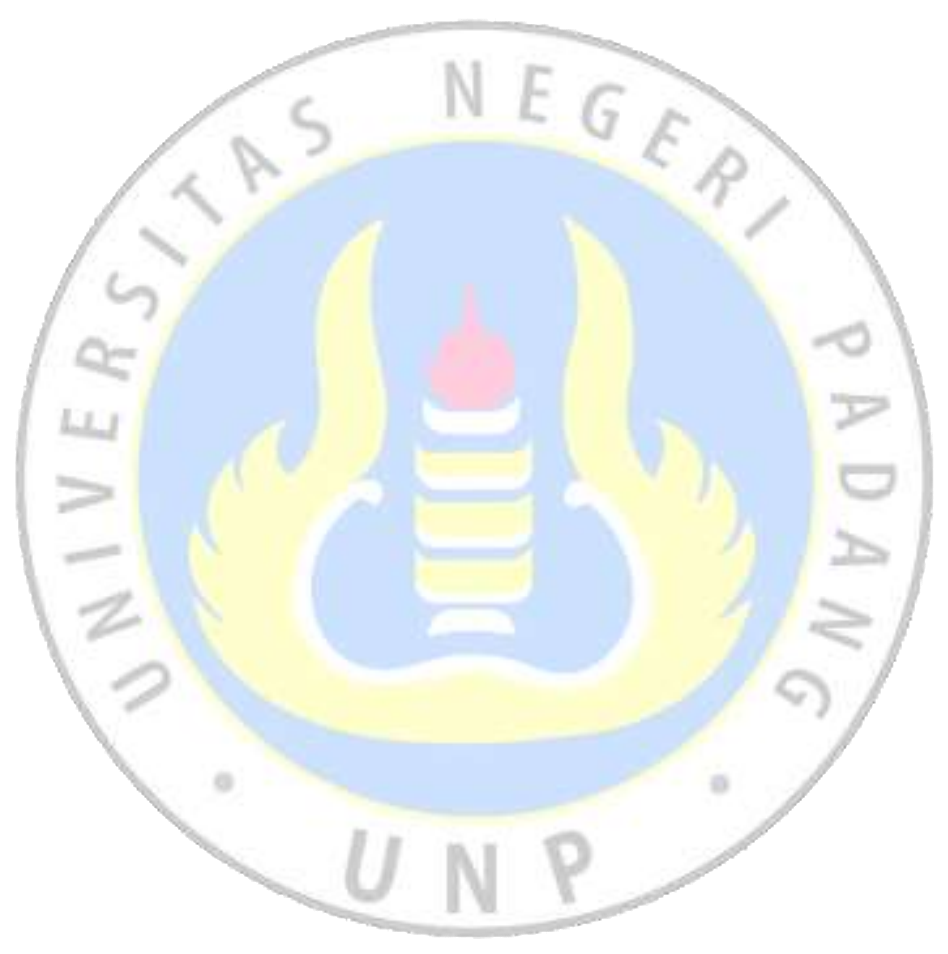

